\title{
Neuroprotective effect of Aronia melanocarpa extract against glutamate- induced oxidative stress in HT22 cells
}

\author{
Hyeon Yong Lee ${ }^{1,2}$, Jin Bae Weon ${ }^{3}$, Gahee Ryu ${ }^{3}$, Woo Seung Yang ${ }^{3}$, Nam Young Kim³ , Myong Ki Kim¹,2
} and Choong Je $\mathrm{Ma}^{3,4^{*}}$

\begin{abstract}
Background: Glutamate (an endogenous excitatory neurotransmitter) at high concentrations contributes to the development of neurodegenerative diseases. Aronia melanocarpa (A. melanocarpa) berries contain anthocyanins and have high antioxidant activities. In this study, we evaluated whether A. melanocarpa berries could protect neuronal cells against glutamate-induced oxidative stress.
\end{abstract}

Method: A. melanocarpa berries exerted a protective effect against cytotoxicity in HT22 mouse hippocampal cells by MTT assay. We evaluated oxidative stress parameters including ROS level, intracellular $\mathrm{Ca}^{2+}$ level, glutathione level and antioxidant enzyme activity in HT22 cells to elucidate the mechanism of its neuroprotective effect.

Results: A. melanocarpa berries decreased glutamate-induced death of HT22 cells. In addition, A. melanocarpa berries reduced ROS and intracellular $\mathrm{Ca}^{2+}$ levels. Glutathione level, antioxidant enzymes, glutathione reductase and glutathione peroxide activities and mitochondrial membrane potential were also increased in HT22 cells.

Conclusion: These results suggested that A. melanocarpa berries protected HT22 cells by exerting an antioxidant effect.

Keywords: Aronia melanocarpa, Neuroprotective effect, Glutamate, Antioxidant effect

\section{Background}

Neurodegenerative disorders, including Alzheimer's disease (AD), Parkinson's disease and Huntington's disease are characterized by loss of neuronal function and memory and cognitive impairment [1]. AD is the most common neurodegenerative disorder [2]. Oxidative stress, including lipid peroxidation, free radical formation, protein oxidation and DNA oxidation, in the central nervous system (CNS) can lead to cell death and contributes to the pathogenesis of various neurodegenerative disorders [3, 4].

Glutamate is an excitatory neurotransmitter that plays a role in learning and memory, and contributes to excitotoxicity in neuronal cells [5]. Glutamate is one of the most important mechanisms known to trigger and

\footnotetext{
* Correspondence: cjma@kangwon.ac.kr

${ }^{3}$ Department of Medical Biomaterials Engineering, College of Biomedical Science, Kangwon National University, Hyoja-2 Dong, Chuncheon 200-701, Republic of Korea

${ }^{4}$ Institute of Bioscience and Biotechnology, Kangwon National University, Chuncheon 200-701, Republic of Korea

Full list of author information is available at the end of the article
}

neuroinflammation and neuronal cell death in CNS disorders. Glutamate-induced excitotoxicity may contribute to the neuronal injury in neurodegenerative diseases such as motor neuron disease and Alzheimer's disease by neuronal injury as anoxia and reperfusion [6].

Excessive glutamate concentration can induce oxidative stress by increasing the production of reactive oxygen species (ROS) and intracellular calcium $\left(\mathrm{Ca}^{2+}\right)$ levels. Glutamate excitotoxicity also results in mitochondrial dysfunction and depletion of antioxidant defense systems, including glutathione (GSH), glutathione peroxidase (GPx) and glutathione reductase (GR) by inhibiting cystine uptake [7-9].

Aronia melanocarpa (black chokeberry: A. melanocarpa), a member of the Rosaceae family, is a fruit with a high content of polyphenols, including anthocyanins (cyanidin glycosides), flavanols, flavonoids (quercetin glycosides), chlorogenic acids, triterpenes, and fibers and caffeic acid derivatives [10]. A. melanocarpa has shown high antioxidant activity, as well as hepatoprotective, 
gastroprotective and anti-inflammatory effects. Recent studies showed that $A$. melanocarpa prevents obesity in C57BL/6 J mice and reduces systolic and diastolic blood pressure $[11,12]$. A. melanocarpa also protects against female skeleton damage due to chronic exposure to $\mathrm{Cd}$ [13]. Cyanidin-3-O-galactoside is a major compound in A. melanocarpa, has considerable antioxidant activity and protects against endothelial dysfunction and vascular failure induced by peroxynitrite $[14,15]$.

Trolox is water-soluble derivative of vitamin $\mathrm{E}$ and antioxidant to reduce oxidative stress. it play as positive control in this study.

The aim of present study was to investigate the neuroprotective effect of Aronia melanocarpa and the possible underlying mechanism against glutamate-induced death of HT22 cells.

\section{Methods}

\section{Plant material and extraction}

A. melanocarpa berries (Danyang, Chungcheongbuk-do, Korea) from a 14-year-old plant were collected and authenticated by Dr. Young Bae Seo, a professor of the College of Oriental Medicine, Daejeon University, Korea. A voucher specimen (CJ200M) has been deposited in the natural products laboratory, the Kangwon National University. A. melanocarpa extract was obtained from the Future Food Research Center (Cheng Ju, Korea).

A. melanocarpa berries were pulverized using a blender after freeze-drying for 3 days (PVTFA 10AT, ILSHIN BioBase, Dongducheon, Korea). Powdered $A$. melanocarpa berries were extracted in $70 \%$ ethanol $(100 \mathrm{~g} / 1 \mathrm{~L})$ at room temperature by maceration and were filtered through a vacuum filter. The extract was concentrated by evaporation (EYELA N-1000, Tokyo Rikakikai Co, Tokyo, Japan) and then freeze-dried for 3 days.

\section{Cell viability assay}

Cell viability was investigated by MTT assay using a method described previously [16]. HT22 cells were seed at a density of $6.7 \times 10^{4} /$ well in 48 -well plates and incubated at $37{ }^{\circ} \mathrm{C}$ in $5 \% \mathrm{CO}_{2}$. After incubation for $24 \mathrm{~h}, 10$ and $100 \mu \mathrm{g} / \mathrm{ml}$ of extract, 1 and $10 \mu \mathrm{g} / \mathrm{ml}$ of cyanidin-3O-galactoside, trolox (positive control, $50 \mu \mathrm{M}$ ) and glutamate were added. Then, cells were incubated for $3 \mathrm{~h}$ with dimethyl thiazolyl diphenyl tetrazolium salt (MTT) $(1 \mathrm{mg} / \mathrm{ml})$ solution, and dimethyl sulfoxide (DMSO) was added to dissolve MTT-formazan crystals. The optical density at $570 \mathrm{~nm}$ was measured using an ELISA reader.

\section{ROS measurement}

2`7`-Dichlorofluorescein diacetate (DCF-DA) was used for measurement of ROS levels. HT22 cells $\left(6.7 \times 10^{4} /\right.$ well in 48-well plates) were treated with 10 and $100 \mu \mathrm{g} /$ $\mathrm{ml}$ of extract, 1 and $10 \mu \mathrm{g} / \mathrm{ml}$ of cyanidin-3-O-galactoside, trolox (positive control, $50 \mu \mathrm{M}$ ) and $2 \mathrm{mM}$ glutamate for $8 \mathrm{~h}$. Then, cells were washed with PBS and incubated in $10 \mu \mathrm{M}$ DCF-DA in Dulbecco's modified Eagle's medium (DMEM) without phenol red for $30 \mathrm{~min}$. Cells were washed twice with phosphate buffer saline (PBS), 1\% Triton X-100 added, and incubated for $10 \mathrm{~min}$ at $37{ }^{\circ} \mathrm{C}$. Fluorescence was measured at an excitation wavelength of $490 \mathrm{~nm}$ and emission wavelength of $525 \mathrm{~nm}$.

\section{Calcium $\left(\mathrm{Ca}^{2+}\right)$ measurement}

Intracellular $\mathrm{Ca}^{2+}$ levels were measured using the Fura2 AM. HT22 cells were plated in 48-well plates and incubated for $24 \mathrm{~h}$ at $37{ }^{\circ} \mathrm{C}$ and $5 \% \mathrm{CO}_{2}$. After incubation, 10 and $100 \mu \mathrm{g} / \mathrm{ml}$ of extract, 1 and $10 \mu \mathrm{g} / \mathrm{ml}$ of cyanidin-3-O-galactoside, Trolox (positive control, $50 \mu \mathrm{M})$ and $2 \mathrm{mM}$ glutamate were treated for $3 \mathrm{~h}$, and then $2 \mu \mathrm{M}$ Fura-AM was added to each well. Cells were then washed three times with HEPES buffer saline. $\mathrm{Ca}^{2+}$ levels were determined by measuring fluorescence intensity at an excitation wavelength of 340 and $380 \mathrm{~nm}$ and emission wavelength of $500 \mathrm{~nm}$.

\section{Mitochondrial membrane potential $(\Delta \Psi)$ measurement}

Mitochondrial membrane potential $(\Delta \Psi)$ change was determined by monitoring the accumulation of the fluorescent dye, rhodamine 123 (Rho123). HT22 cells were treated with $2 \mathrm{mM}$ glutamate, 10 and $100 \mu \mathrm{g} / \mathrm{ml}$ of $A$. melanocarpa extract and 1 and $10 \mu \mathrm{g} / \mathrm{ml}$ of cyanidin-3O-galactoside. HT22 cells were then stained with Rho123 for $15 \mathrm{~min}$ at $37{ }^{\circ} \mathrm{C}$ and washed. The Rho123 concentration was measured by spectrofluorometry at an excitation wavelength of $488 \mathrm{~nm}$ and emission wavelength of $520 \mathrm{~nm}$.

\section{GSH measurement}

Total GSH was measured by an enzymatic cycling method based on the reduction of $5^{\prime}, 5^{\prime}$-dithiobis 2nitrobenzoic acid (DTNB) with GSH reductase and nicotinamide adenine dinucleotide phosphate (NADPH). Cells were treated with extract, cyanidin-3-O-galactoside and glutamate for $8 \mathrm{~h}$ and washed with $0.2 \mathrm{M}$ phosphate buffer ( $\mathrm{pH}$ 7.4). Cells were lysed with sulfosalicylic acid and centrifuged at $3000 \mathrm{~g}$ for $30 \mathrm{~min}$ at $4{ }^{\circ} \mathrm{C}$ to collect supernatants. Supernatants were mixed with 5 units $/ \mathrm{mL}$ glutathione disulfide reductase, $0.3 \mathrm{mM} \mathrm{NADPH}$ and $0.5 \mathrm{mM}$ DTNB. The reaction absorbance at $412 \mathrm{~nm}$ was measured within $15 \mathrm{~min}$.

\section{Antioxidant enzyme, glutathione reductase and glutathione peroxidase assays}

HT22 cells were treated with extract, cyanidin-3-O-galactoside and glutamate for $8 \mathrm{~h}$. Cells were washed with 


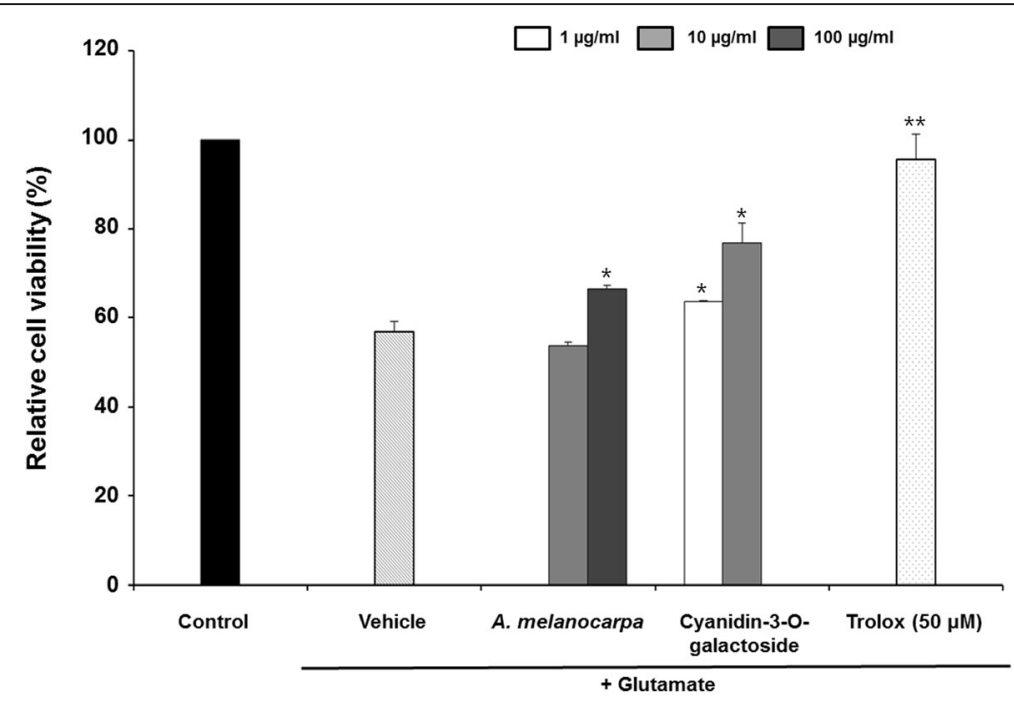

Fig. 1 Effect of A. melanocarpa extract (10 and $100 \mu \mathrm{g} / \mathrm{ml}$ ) and cyanidin-3-O-galactoside (1 and $10 \mu \mathrm{g} / \mathrm{ml}$ ) on glutamate-induced death of HT22 cells. Data are means \pm S.D. ${ }^{*} p<0.05$ versus the glutamate-treated group

$0.2 \mathrm{M}$ phosphate buffer ( $\mathrm{pH} 7.4)$ and lysed with sulfosalicylic acid. After centrifugation (3000 g for $30 \mathrm{~min}$ at $4{ }^{\circ} \mathrm{C}$ ), supernatants were collected. Glutathione reductase (GR) was measured by monitoring the reduction of oxidized GSH (GSSG) in the presence of NADPH. Glutathione peroxidase activity was determined by quantifying the rate of oxidation of GSH to GSSG. The decrease in absorbance at $340 \mathrm{~nm}$ was measured using a spectrophotometer.

\section{Statistics}

All data were expressed as means \pm S.D. Significant differences were analyzed by one-way analysis of variance
(ANOVA) followed by Tukey's post hoc test. Statistical significance was set at $P<0.05,0.01$ and 0.001 .

\section{Results}

Neuroprotective effect of $A$. melanocarpa on glutamateinduced cell death in HT22 cells

We evaluated the neuroprotective effects of A. melanocarpa extract in HT22 cells (Fig. 1). A. melanocarpa extract exhibited significant neuroprotective effects by reducing glutamate-induced cell death to $16.81 \pm 35.38 \%$ (relative protection at $100 \mu \mathrm{g} / \mathrm{ml}$ ). Cyanidin-3-O-galactoside also significantly protected HT22 cells against glutamate-induced neurotoxicity, with relative protection of $35.38 \pm 12.43 \%$ at $10 \mu \mathrm{g} / \mathrm{ml}$.

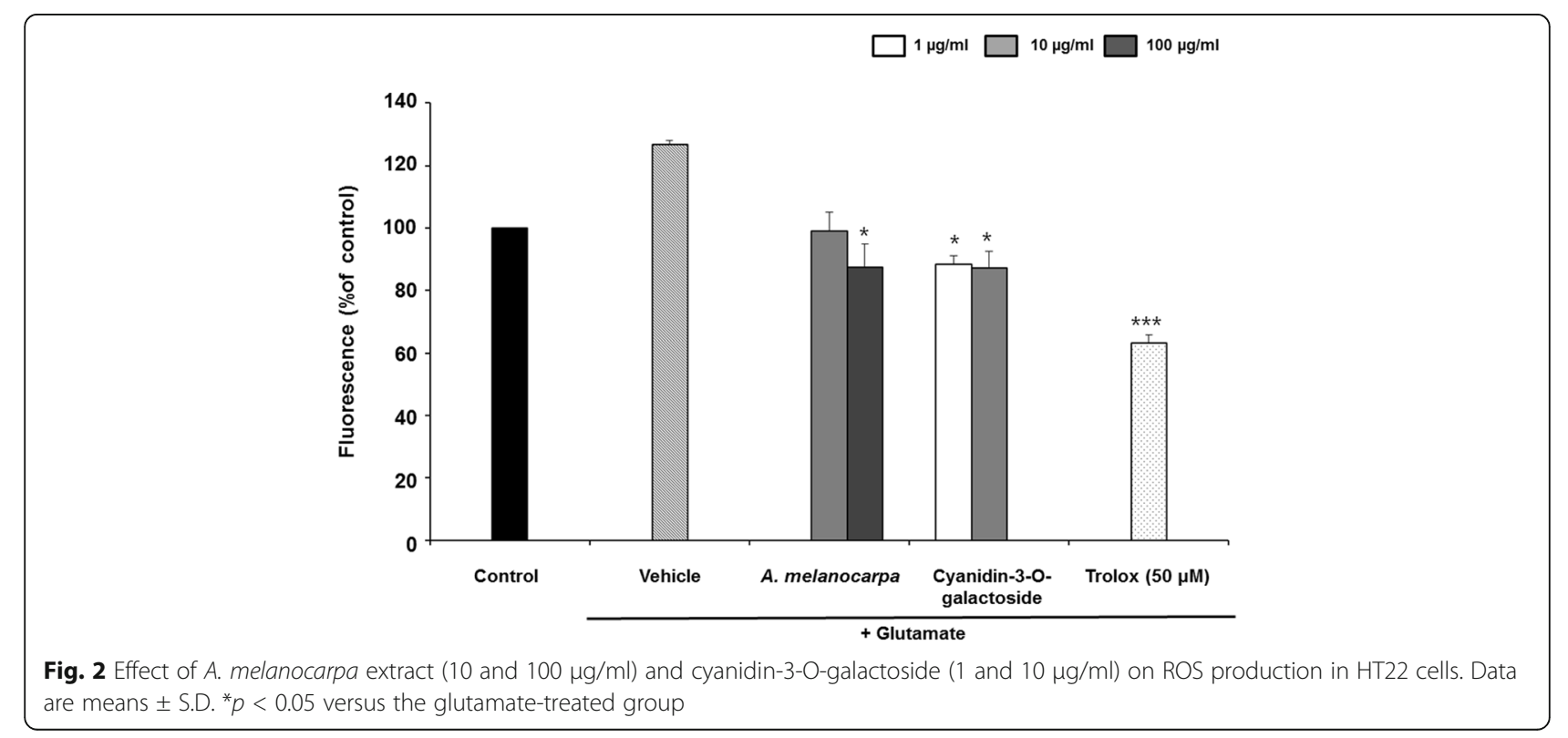




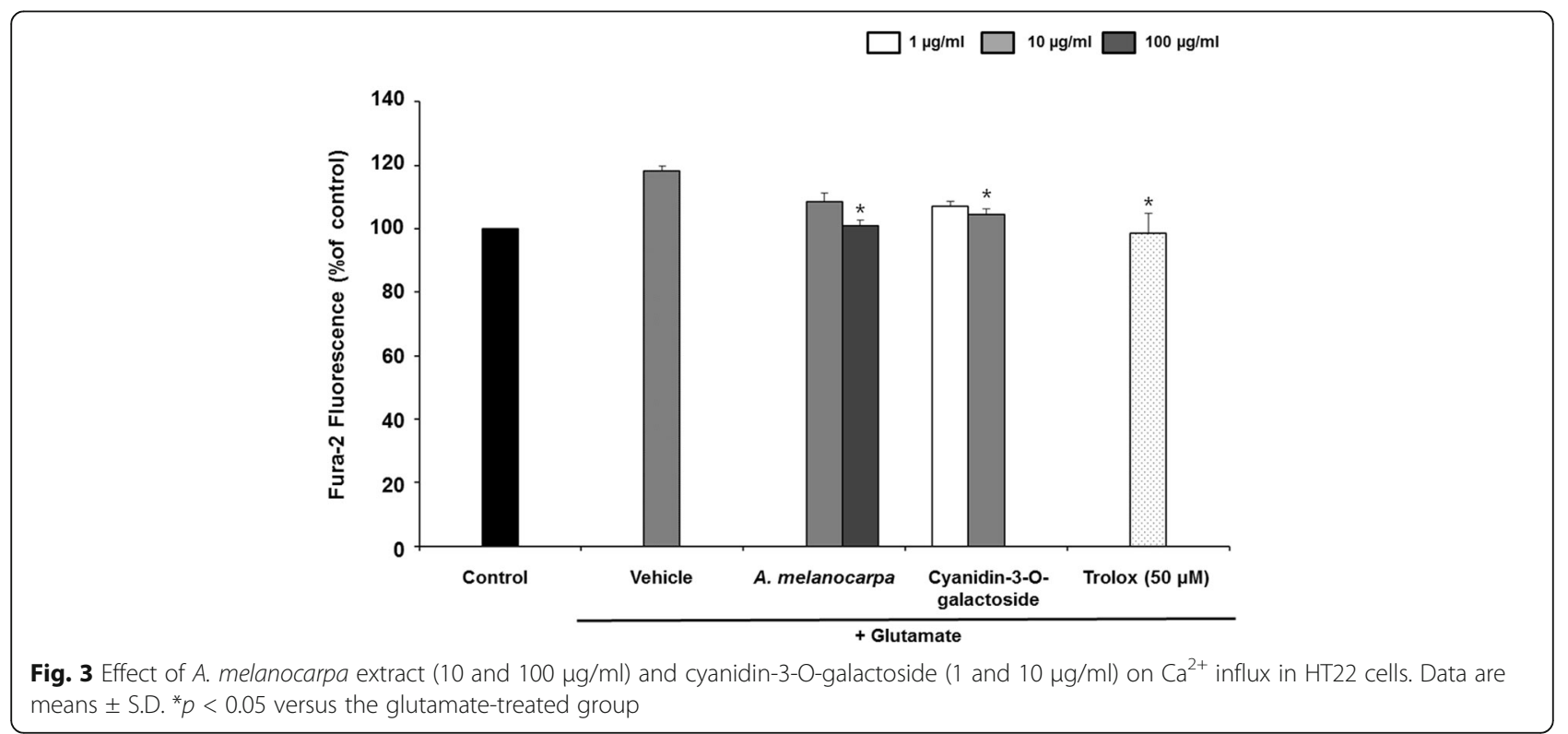

\section{ROS production}

Inhibition of ROS production by A. melanocarpa extract was evaluated using $27^{`}$-dichlorofluorescein diacetate (Fig. 2). Glutamate treatment increased the ROS level in HT22 cells compared to the control (126.7 $\pm 1.32 \%)$. A. melanocarpa extract at $100 \mu \mathrm{g} / \mathrm{ml}$ significantly decreased glutamate-induced ROS production to $87.32 \pm 7.50 \%$ $(p<0.05)$. Cyanidin-3-O-galactoside at $10 \mu \mathrm{g} / \mathrm{ml}$ also decreased ROS production to $87.23 \pm 5.30 \%$.

\section{Intracellular $\mathrm{Ca}^{2+}$ production}

High concentrations of glutamate lead to intercellular $\mathrm{Ca}^{2+}$ accumulation. We investigated intracellular $\mathrm{Ca}^{2+}$ levels using Fura-AM to determine the effect of $A$. melanocarpa extract in HT22 cells (Fig. 3). A. melanocarpa extract at $100 \mu \mathrm{g} / \mathrm{ml}$ significantly decreased the intracellular $\mathrm{Ca}^{2+}$ concentration in HT22 cells compared to glutamate-treated cells $(100.81 \pm 1.89 \%(p<0.05)$ at $100 \mu \mathrm{g} / \mathrm{ml}$ ). Cyanidin-3-O-galactoside at $10 \mu \mathrm{g} / \mathrm{ml}$ also significantly decreased intracellular $\mathrm{Ca}^{2+}$ levels to $104.37 \pm 1.80 \%$.

\section{Mitochondrial membrane potential $(\Delta \Psi)$}

We investigated the effect of $A$. melanocarpa extract on mitochondrial membrane potential $(\Delta \Psi)$ in HT22 cells using Rho123 dye (Fig. 4). Glutamate-treated HT22 cells exhibited a decreased mitochondrial membrane potential to $80.94 \pm 8.70 \%$. A. melanocarpa extract at $100 \mu \mathrm{g} / \mathrm{ml}$

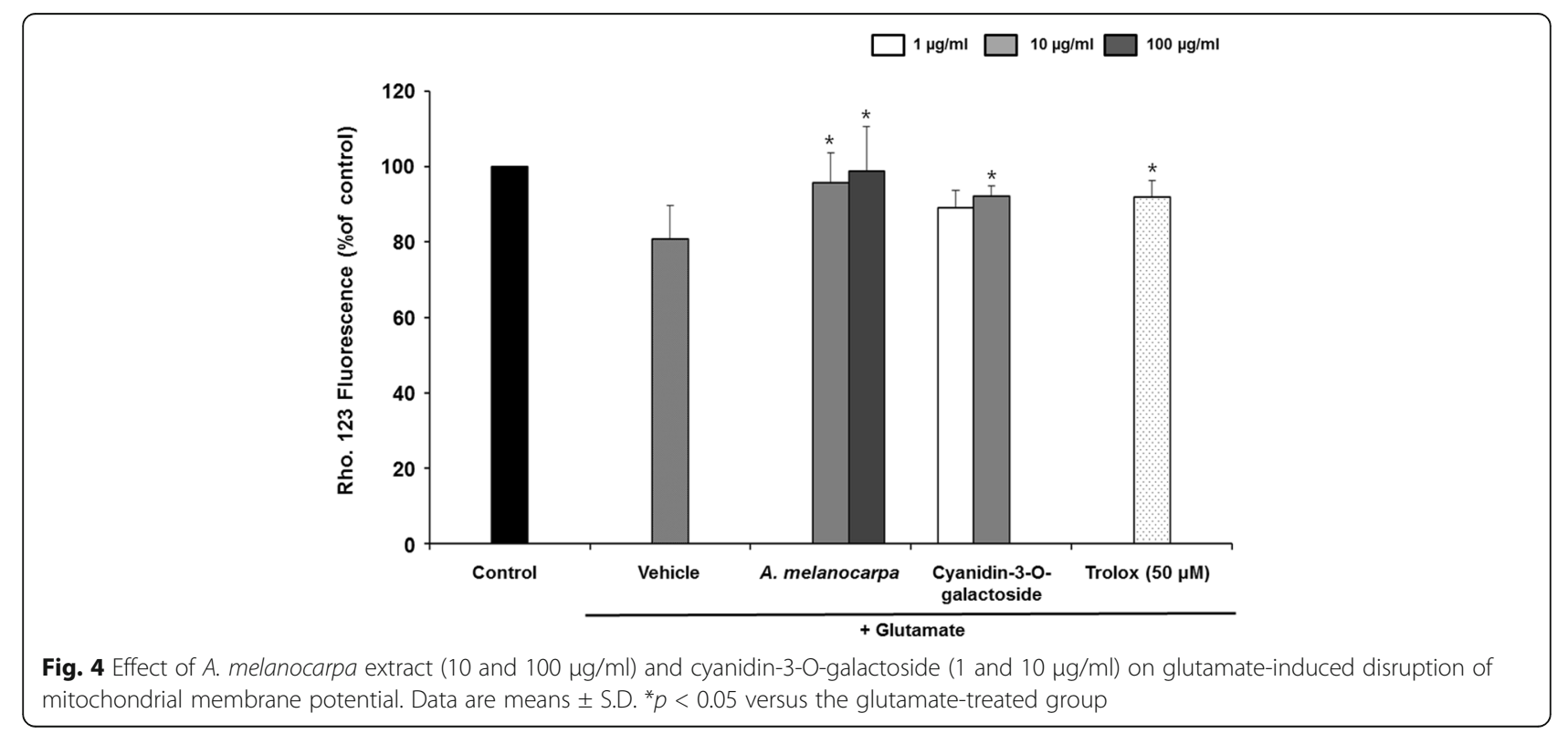




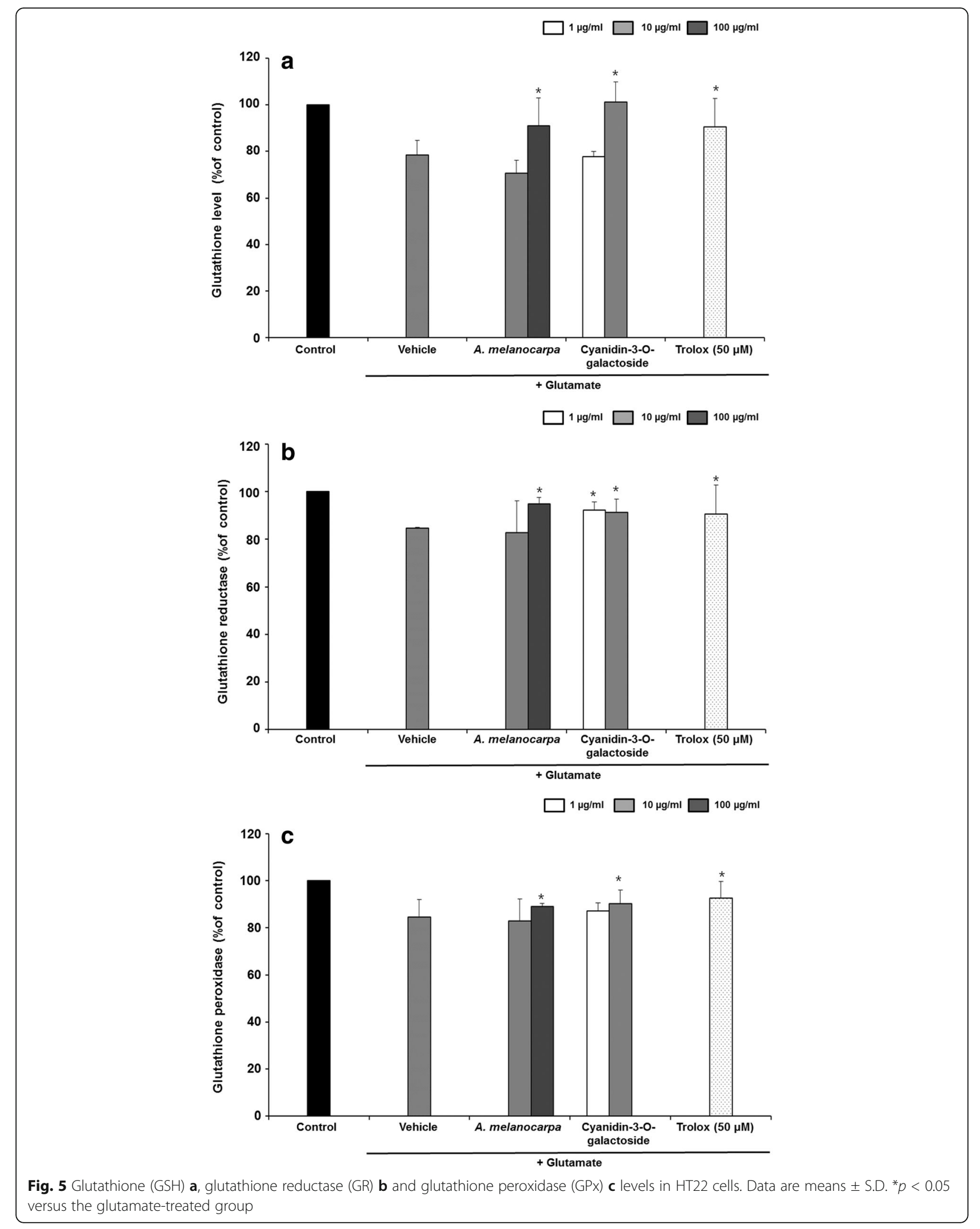


significantly increased the mitochondrial membrane potential to $98.84 \pm 11.90 \%$ of the control. In addition, Cyanidin-3-O-galactoside improved the mitochondrial membrane potential decreased by glutamate $(92.25 \pm 2.62 \%$ at $10 \mu \mathrm{g} / \mathrm{ml})$.

\section{GSH level and GR and GPx activity}

We evaluated the effect of $A$. melanocarpa extract on GSH level, and GR and GPx activity in HT22 cells (Fig. 5). A. melanocarpa extract increased the GSH level. Exposure to glutamate increased the GSH level by $78.56 \pm 6.26 \%$, GR activity by $84.79 \pm 0.29 \%$ and GPx activity by $89.04 \pm 1.36 \%$, whereas A. melanocarpa extract prevented the glutamate-induced depletion of GSH level $(90.92 \pm 12.19 \%$ at $100 \mu \mathrm{g} / \mathrm{mL})$, GR activity $(94.90 \pm 2.68 \%$ at $100 \mu \mathrm{g} / \mathrm{mL})$ and GPx activity $(89.05 \pm 1.36 \%$ at $100 \mu \mathrm{g} / \mathrm{mL})$. Cyanidin-3-O-galactoside also significantly increased the GSH level, GR activity and GPx activity.

\section{Discussion}

This study demonstrated that A. melanocarpa extract protected mouse hippocampal HT22neuronal cells against glutamate-induced death.

High levels of glutamate excitotoxicity can lead to neuronal cell death by oxidative stress. It is also involved in intercellular $\mathrm{Ca}^{2+}$ influx and reactive oxygen species (ROS) generation via NMDA receptor [17]. ROS, including hydroxyl radical $\left(\mathrm{OH}^{-}\right)$, superoxide anion $\left(\mathrm{O}_{2}^{-}\right)$and hydrogen peroxide $\left(\mathrm{H}_{2} \mathrm{O}_{2}\right)$, are generated in cells and lead to death due to DNA damage, protein oxidation, and lipid peroxidation [18]. Intercellular $\mathrm{Ca}^{2+}$ influx contributes to excessive ROS production and causes depolarization of the mitochondrial membrane. GSH is an important antioxidant involved in nutrient metabolism, DNA synthesis, signal transduction and cell proliferation in the CNS. GR and GPx are critical enzymes for the production of GSH. A high concentration of glutamate was involved in depletion of GSH by inhibiting cysteine uptake into cells [19]. Depletion of GSH or antioxidant enzymes, such as GR and GPx, leads to neuronal cell death [20]. Mitochondria play an important role in neuronal cell death. Mitochondrial dysfunction results in ROS production and cell apoptosis and is indicated by loss of the mitochondrial membrane potential [21]. A high glutamate level also induced a decrease in the mitochondrial membrane potential in cells in the CNS.

HT22 cells, an immortalized mouse hippocampal cell line, are used in vitro for mechanistic studies related to glutamate-induced cell death by oxidative stress [22].

Our results showed that A. melanocarpa extract protected HT22 cells against glutamate-induced cell death by inhibiting $\mathrm{ROS}$ generation and $\mathrm{Ca}^{2+}$ influx. $A$. melanocarpa extract also restored GSH, GPx and GR activity and increased the mitochondrial membrane potential. Therefore, the neuroprotective effect of $A$. melanocarpa extract against glutamate-induced cell death was likely mediated through attenuation of oxidative stress.

Cyanidin-3-O-galactoside is a major compound in $A$. melanocarpa extract. A previous study demonstrated that cyanidin-3-O-galactoside exerted an antioxidant effect and a cognitive effect on spatial memory, and regulates hippocampal ERK expression in senescenceaccelerated mice [23]. Thus, cyanidin-3-O-galactoside may be involved in the neuroprotective effect of $\mathrm{A}$. melanocarpa extract.

\section{Conclusion}

In conclusion, $A$. melanocarpa extract protected neuronal cells against glutamate-induced death due to its antioxidant activity. Therefore, A. melanocarpa extract may have therapeutic potential for neurodegenerative diseases, such as Alzheimer's disease.

\section{Acknowledgement}

This work was supported by the company leading joint research corporation foundation and R\&D funded by the Ministry of Science, ICT and Future Planning (2015 K000319).

\section{Funding}

None.

Availability of data and materials

Data sharing is not applicable to this article as no datasets were generated or analysed during the current study.

\section{Authors' contribution}

$H Y L$, Conception \& design, acquisition of the data, analysis \& interpretation of the data, drafting of the article. JBW, Conception \& design, acquisition of the data, analysis \& interpretation of the data, statistical expertise. GR, Administrative, technical, or logistic support. WSY, Collection \& assembly of data, obtaining of funding. NYK, Collection \& assembly of data, obtaining of funding. MKK, Conception \& design. CJM, Conception \& design, final approval of the article. All authors read and approved the final manuscript.

\section{Competing interests}

The authors have declared that there are no conflicts of interest.

\section{Consent for publication}

We give our consent for information about myself/my child or ward/my relative (circle as appropriate) to be published in. BMC Complementary and Alternative Medicine.

We understand that the text and any pictures or videos published in the article will be freely available on the internet and may be seen by the general public. The pictures, videos and text may also appear on other websites or in print, may be translated into other languages or used for commercial purposes. We have been offered the opportunity to read the manuscript.

Ethics approval and consent to participate

We do not involved human subjects, human material, or human data in this study.

\section{Publisher's note}

Springer Nature remains neutral with regard to jurisdictional claims in published maps and institutional affiliations. 


\section{Author details}

Department of Food Science and Engineering, Seowon University, Cheongju 361-742, Republic of Korea. ${ }^{2}$ Future Food Research Center, 377-3 Musimsero, Seowon-gu, Cheongju, Chungbuk 28674, Republic of Korea. ${ }^{3}$ Department of Medical Biomaterials Engineering, College of Biomedical Science, Kangwon National University, Hyoja-2 Dong, Chuncheon 200-701, Republic of Korea. ${ }^{4}$ Institute of Bioscience and Biotechnology, Kangwon National University, Chuncheon 200-701, Republic of Korea.

Received: 14 December 2016 Accepted: 1 April 2017 Published online: 11 April 2017

\section{References}

1. Crapper DR, DeBoni U. Brain aging and Alzheimer's disease. Can Psychiatric Assoc J. 1978;23(4):229-33.

2. Swerdlow RH. Pathogenesis of Alzheimer's disease. Clin Interv Aging. 2007; 2(3):347-59.

3. Markesbery WR. Oxidative stress hypothesis in Alzheimer's disease. Free Radic Biol Med. 1997;23(1):134-47.

4. Fukui $\mathrm{M}$, Song JH, Choi J, Choi HJ, Zhu BT. Mechanism of glutamateinduced neurotoxicity in HT22 mouse hippocampal cells. Eur J Pharmacol. 2009;617:1-11

5. Hynd MR, Scott HL, Dodd PR. Glutamate-mediated excitotoxicity and neurodegeneration in Alzheimer's disease. Neurochem Int. 2004;45(5): 583-95.

6. Schubert D, Piasecki D. Oxidative glutamate toxicity can be a component of the excitotoxicity cascade. J Neurosci. 2001;21:7455-62.

7. Choi DW. Glutamate neurotoxicity in cortical cell cultures is calcium dependent. Neurosci Lett. 1985;58:293-7.

8. Tan S, Wood M, Maher P. Oxidative stress induces a form of programmed cell death with characteristics of both apoptosis and necrosis in neuronal cells. J Neurochem. 1998;71:95-105.

9. Murphy TH, Miyamoto M, Sastre A, Schnaar RL, Coyle JT. Glutamate toxicity in neuronal cell line involves inhibition of cystine transport leading to oxidative stress. Neuron. 1989;2:1547-58.

10. Oszmiański J, Wojdylo A. Aronia melanocarpa Phenolics and their antioxidant activity. Eur Food Res Technol. 2005;221(6):809-13.

11. Ciocoiu M, Badescu L, Miron A, Badescu M. The involvement of a polyphenol-rich extract of black chokeberry in oxidative stress on experimental arterial hypertension. Evid Based Complement Alternat Med. 2013; doi:10.1155/2013/912769.

12. Baum II, Shouse SA, Gilbert W, Prior RL, Howard LR. The effect of black chokeberry (Aronia melanocarpa) on the prevention of obesity in C57BL/6J mice. FASEB J. 2013;27:861-4.

13. Brzóska MM, Rogalska J, Galazyn-Sidorczuk M, Jurczuk M, Roszczenko A, Tomczyk M. Protective effect of Aronia melanocarpa polyphenols against cadmium-induced disorders in bone metabolism: a study in a rat model of lifetime human exposure to this heavy metal. Chem Biol Interact. 2015;229: 132-46.

14. Natella F, Nardini M, Giannetti I, Dattilo C, Scaccini C. Coffee drinking influences plasma antioxidant capacity in humans. J Agric Food Chem. 2002;50(21):6211-6.

15. Serraino I, Dugo L, Dugo P, Mondello L, Mazzon E, Dugo G, Caputi AP, Cuzzocrea S. Protective effects of cyanidin-3-O-glucoside from blackberry extract against peroxynitrite-induced endothelial dysfunction and vascular failure. Life Sci. 2003:73(9):1097-114.

16. Weon JB, Lee B, Yun BR, Lee J, Ma CJ. Neuroprotective effects of 4, 5dimethoxypyrocatechol isolated from Cynanchum paniculatum on HT22 cells. Pharmacog Mag. 2014;10(38):161-4.

17. Butterfield DA, Pocernich CB. The glutamatergic system and Alzheimer's disease: therapeutic implications. CNS Drugs. 2003;17(9):641-52.

18. Suzuki YS, Forman HJ, Sevanian A. Oxidants as stimulators of signal transduction. Free Radic Biol Med. 1997;22:269-85.

19. Albrecht P, Lewerenz J, Dittmer S, Noack R, Maher P, Methner A Mechanisms of oxidative glutamate toxicity: the glutamate/cystine antiporter system xc- as a neuroprotective drug target. CNS Neurol Disord Drug Targets. 2010;3:373-82.

20. Kane DJ, Sarafian TA, Anton R, Hahn H, Gralla EB, Valentine JS, Ord T, Bredesen DE. BCl-2 inhibition of neuronal death: decreased generation of reactive oxygen species. Science. 1993;262:1274-7.
21. Ankarcrona M, Dypbukt JM, Bonfoco E, Zhivotovsky B, Orrenius S, Lipton SA, Nicotera P. Glutamate-induced neuronal death: a succession of necrosis or apoptosis depending on mitochondrial function. Neuron. 1995;15(4):961-73.

22. Liu J, Li L, Suo WZ. HT22 hippocampal neuronal cell line possesses functional cholinergic properties. Life Sci. 2009;84:267-71.

23. Tan L, Yang HP, Pang W, Lu H, Hu YD, Li J, Lu SJ, Zhang WQ, Jiang YG. Cyanidin-3-O-galactoside and blueberry extracts supplementation improves spatial memory and regulates hippocampal ERK expression in senescenceaccelerated mice. Biomed Environ Sci. 2014:27(3):186-96.

\section{Submit your next manuscript to BioMed Central and we will help you at every step:}

- We accept pre-submission inquiries

- Our selector tool helps you to find the most relevant journal

- We provide round the clock customer support

- Convenient online submission

- Thorough peer review

- Inclusion in PubMed and all major indexing services

- Maximum visibility for your research

Submit your manuscript at www.biomedcentral.com/submit
BioMed Central 